\title{
Kertas Minor dari Timur: Koran Tribun Timur 2004-2016
}

\author{
Adi Sucipto, Patahuddin, M. Rasyid Ridha \\ Pendidikan Sejarah FIS UNM \\ ditosucipto5@gmail.com
}

\begin{abstract}
Abstrak
Kertas Minor dari Timur adalah sebuah judul yang membahas tentang sebuah Koran harian yang ada di Makassar. Maksud dari kata Kertas dalam judul tersebut adalah penyebutan untuk Koran Tribun Timur. Sedangkan Minor, dikarenakan Koran Tribun Timur adalah Koran yang terbilang masih muda atau baru, namun dapat menyaingi bahkan mengungguli Koran yang telah terbit sebelumnya. Untuk Timur sendiri, karena Koran Tribun Timur berada di wilayah Indonesia Timur, yaitu Makassar. Penelitian ini membahas tentang proses lahirnya dan perkembangan Koran Tribun Timur sejak tahun 2004-2016. Hasil penelitian menunjukkan bahwa Koran Tribun Timur mulai digagas pada tahun 2003, dan mulai terbit untuk pertama kali pada 9 Februari 2004. Koran Tribun Timur berada di bawah naungan PT. Bosowa Media Grafika. Hal menarik dari latar belakang berdirinya Koran Tribun Timur ini adalah keterlibatan Jusuf Kalla. Dalam proses perkembangannya Koran Tribun Timur mengalami dua kali pergantian pemimpin redaksi yaitu Uki M Kurdi dan Dahlan Dahi. Oplah dan readership mengalami perkembangan, rubrik pun mengalami penambahan guna memenuhi kebutuhan informasi masyarakat khususnya Kota Makassar. Koran Tribun Timur memiliki keunikan dibandingkan Koran lain, yaitu dengan adanya rubrik Citizen Report. Dengan adanya rubrik tersebut, maka masyarakat dapat mengirim berita ke Tribun Timur dan setelah diseleksi akan diterbitkan. Sehingga berita dari Koran Tribun Timur bervariasi karena masyarakat yang mengirimkan berita berasal dari latar belakang yang berbeda-beda. Penelitian ini menggunakan metode penelitian sejarah, yaitu heuristik (mencari dan mengumpulkan sumber), kritik sumber (kritik ekstern dan kritik intern), interpretasi (penafsiran sumber) dan historiografi (penulisan sejarah). Metode pengumpulan data dilakukan dengan cara melakukan penelitian pustaka, penelitian lapangan (wawancara) dan dokumentasi. Akhir dari penelitian, ditarik kesimpulan bahwa proses lahirnya Koran Tribun Timur disebabkan oleh tingginya populasi penduduk Makassar, tingginya daya beli, permintaan Jusuf Kalla untuk menerbitkan Koran di Makassar, sera kurangnya koran harian yang terbit di Makassar.
\end{abstract}

\section{Kata Kunci : Tribun Timur, Media, Makassar}

\begin{abstract}
A minor Paper from The East is a title that cover a daily newspaper in Makassar. The meaning of Paper in the rubric is the mention for Tribun Timur newspaper. While the Minor, because Tribun Timur newspaper is a newspaper that is fairly young or new, but can compete and even outperformed previously published newspaper. While From the East, because the Tribun Timur newspaper is in eastern Indonesia, namely Makassar. This research discusses about the birth process and the development of eastern tribune newspaper since 2004- 2016. The results showed that the Tribun Timur newspaper began to be initiated in 2003 and began to be published for the first time on 9 Februari 2004. Tribun Timur newspaper is under the auspices of PT.Bosowa Media Grafika. It is interesting from the background of the birth of the Tribun Timur newspaper experienced twice the turn of editor in chief, namely Uki M Kurdi and Dahlan Dahi. Oplah and readership progressed, the rubric also increased progressed, the rubric also increased to meet the information needs of the special community of Makassar. The Tribun Timur newspaper has a bigger thrill than the newspaper with the rubric citizen
\end{abstract}


report. With the rubric, then the selection will be published. So the tapes from the Tribun Timur newspapervary because the people who send the news come from different backgrounds. This study uses historical research methods, namely heuristic (searching and collecting resources), source criticism, interpretation (interpretating sourse) and historiography (historical writing). Methods of data collection is done by doing literature research, field research (interviews) and documentation. The end of the research, drawn the conclusion that the birth of the Tribun Timur newspaper caused by the high population of Makassar, high buying power, Jusuf Kalla request to publish newspapers in Makassar and the lack of daily newspaper published in Makassar.

\section{Keywords : Tribune East, Media, Makassar.}

\section{A. Pendahuluan}

Koran atau Surat kabar merupakan salah satu media cetak yang digemari masyarakat dalam mencari informasi. Topik berita dalam Koran bisa berupa even politik, kriminalitas, olahraga, tajuk rencana, maupun cuaca. Dalam beberapa Koran juga memuat cerpen, komik, TTS (teka-teki silang) dan hiburan lainnya.

Di Perancis, industry surat kabar berkembang bertentangan dengan Press Law tahun 1881, yang menyatakan kebebasan pers. Surat kabar dinilai penting untuk kepentingan demokrasi dan hiburan. Bukan hanya untuk kaum elit saja, melainkan untuk seluruh masyarakat. Sejak Perang Dunia kedua, topik pembahasan dalam Surat kabar mulai berkurang karena lebih banyak menyangkut tentang perang dan kondisi politik dan sirkulasinya terhenti pada tahun 1940-an (Michael, 2004).

Di Kota Makassar terdapat beberapa Koran yang berkembang dan familiar di mata masyarakat. Salah satunya adalah Koran Tribun Timur. Latar belakang lahirnya Koran Tribun Timur dipengaruhi oleh beberapa faktor, hal tersebut menjadi daya tarik tersendiri untuk diketahui dalam jurnal ini. Koran Tribun Timur adalah Koran harian Makassar yang pertama kali terbit pada tanggal 9 Februari 2004. Koran Tribun Timur memiliki wilayah edar meliputi dua provinsi utama di Sulawesi, yaitu Sulawesi Selatan dan Sulawesi Barat.

Pada awal perjalanannya, Koran Tribun Timur berkantor di Gedung Mercedes Jl. Perintis Kemerdekaan KM 9 Tamalanrea, Makassar. Selanjutnya pada 3
April 2004, redaksi Koran Tribun Timur pindah ke Jl. Cendrawasih No.403 Makassar. Koran Tribun Timur merupakan salah satu koran daerah Kompas Gramedia yang dikelola oleh PT. Indopersda Primamedia (Persda Network), Divisi Koran Daerah Kompas Gramedia, dan untuk menerbitkannya Kompas Gramedia bekerja sama dengan Bosowa Group (Timur, 2009). Pada perkembangannya, baik pada masa pemimpin redaksi Uki M Kurdi maupun Dahlan dahi terdapat karyawan yang keluar dari Tribun Timur yang disebabkan oleh ketidak mampuan menyesuaikan jam kerja yang padat.

Kehadiran Koran Tribun Timur ikut menambah deretan media yang sebelumnya telah terbit dan mendapat tempat di mata publik Kota Makassar. Koran-koran tersebut seperti Harian Fajar, Berita Kota, Ujung Pandang Ekspress dan Harian Pedoman Rakyat. Meskipun diantara Koran-koran sebelumnya, Koran Tribun Timur merupakan Koran termuda. Namun dalam perkembangannya, Koran Tribun timur mampu menyaingi bahkan melampaui Koran-koran yang telah terbit sebelumnya.

Kajian tentang Koran Tribun Timur telah didapatkan cukup melimpah, diantaranya Skripsi Nur Azizah, 2016, dengan judul Strategi Harian Tribun Timur Meningkatkan Jumlah Pengiklanan di Kota Makassar. Dalam Skripsi ini membahas secara detail tentang cara Koran Tribun Timur memperoleh pengiklan yang banyak. Strategi-strategi yang digunakan dalam meningkatkan jumlah iklan yang join 
dengan Koran Tribun Timur dikupas sampai tuntas. Namun, dalam Skripsi ini tidak membahas tentang latar belakang dan proses lahirnya, serta perkembangan dari Koran Tribun Timur. Serta Skripsi Syahrul Ramadhan, 2012, dengan judul Analisis Penerapan Konsep Penyeimbang Lini (Line Balancing) pada Sistem Produksi Percetakan Harian Tribun Timur. Dalam skripsi ini membahas tentang sistem produksi percetakan pada Koran Tribun Timur. Membahas tentang manfaat atau fungsi penerapan konsep penyeimbang Lini pada sistem produksi percetakan Koran Tribun Timur. Namun dalam Skripsi ini belum ada yang mengkaji tentang proses lahirnya dan perkembangan dari Koran Tribun Timur dari segi historis. Hal tersebut yang mendorong penulis untuk mengkaji lebih dalam tentang Koran Tribun Timur di Makassar (2004-2016) sebagai objek penelitiannya. Dimana penulis akan menjelaskan proses lahirnya, perkembangan, serta peran Koran Tribun Timur di Makassar.

\section{B. Metode Penelitian}

Dalam pembahasan mengenai Koran tribun timur di Makassar, penulis menggunakan jenis penelitian sejarah dengan menerapkan metode sejarah dalam penelitian dan penulisannya. Sebagaimana dengan penulisan sejarah lainnya, dalam penulisan skripsi ini pun juga ditempuh empat tahapan atau teknik dalam merekonstruksi peristiwa yang pernah terjadi di masa lampau yaitu heuristik (pengumpulan sumber), kritik sumber (eksternal/bahan dan internal/isi), interpretasi (penafsiran) dan historiografi (penulisan kisah sejarah)(Madjid, 2012)Penelitian ini dilakukan dengan teknik wawancara dengan Pihak-pihak yang terdapat dalam struktur kerja dari koran tribun timur yaitu Ronal Ngantung, Soni Marianto, Nurul Adha, dan pihak yang memiliki kapasitas untuk mendukung fokus penelitian ini yaitu Muhary Wahyu Nurba, Hamdan Ihsan, Hairul Fadli. Serta dengan teknik kajian kepustakaan dengan cara mengkaji sumber bacaan yang relevan dengan tujuan melengkapi data primer seperti Koran (Koran Tribun Timur edisi 9 Februari 2004, Edisi 4 Agustus 2008, dan edisi 3 April 2016) dokumen dan kepustakaan (buku, hasil penelitian (Hasil survei Nielsen Media Research)dan jurnal).

\section{Tinjauan Umum Penelitian}

Makassar merupakan Kota terbesar di wilayah Indonesia Timur. Makassar (dahulu daerah tingkat II berstatus kota madya; dari 1971 hingga 1999 secara resmi dikenal sebagai Ujung Pandang) adalah sebuah kota madya dan sekaligus ibu kota provinsi Sulawesi Selatan. Secara geografis, Kota Makassar terletak di pesisir pantai barat bagian selatan Sulawesi Selatan menghadap Selat Makassar, pada koordinat antara 119o 18' 27,97" - 119o 32'31,03” Bujur Timur (BT) dan 5o 30' 18" - 5o 14' 49" Lintang Selatan (LS). Ketinggian kota ini bervariasi antara $0-25$ meter dari permukaan laut, suhu udara antara $20 \mathrm{o}-$ 32o C, memiliki garis pantai sepanjang 32 $\mathrm{km}$ dan areal seluas $175,77 \mathrm{~km} 2$, serta terdiri dari 14 kecamatan, dan 143 kelurahan (PRWLSDNH, 2004). Kota ini termasuk Kota kosmopolis dan Kota terbesar, dengan jumlah penduduk kurang lebih 1, 25 juta jiwa, banyak suku bangsa tinggal di sini. Di Kota ini ada suku Makassar, Bugis, Toraja dan Mandar. Terdapat pula komunitas Tionghoa yang cukup besar. (Anon., 2004)

Pada awal perjalanannya, Koran Tribun Timur berkantor di Jl. Perintis Kemerdekaan $\quad$ KM 9 Tamalanrea Makassar. Selanjutnya pada 3 April 2004, Redaksi Koran Tribun Timur pindah ke Jl. Cendrawasih No. 403 Makassar. Hal ini dikarenakan belajar dari pengalaman Koran Tribun Kaltim yang sudah terbit lebih awal, dimana Koran tersebut memiliki satu lokasi yang di dalamnya terdapat Kantor, percetakan, juga gudang. Hal ini dapat memudahkan operasional dalam penerbitan Koran. Sehingga dipilih lokasi di Jl. Cendrawasih untuk mendirikan 
Kantor dari Koran Tribun Timur (Ngantung, 2017).

\section{Pembahasan}

\section{Koran di Makassar}

Di Kota Makassar, Koran pertama kali diperkenalkan oleh bangsa Belanda. Hal ini terjadi karena kondisi masyarakat pada saat itu dimana rata-rata pengetahuan orang Belanda lebih baik dari pada orang Indonesia dalam berbagai hal, termasuk dalam hal pers. Selain itu dari segi ekonomi dan teknis, orang Belanda juga jauh lebih baik dari pada orang Indonesia.

Seiring berjalannya waktu, munculah masyarakat terdidik yang melakukan perlawanan dengan cara lebih modern yaitu melemahkan struktur pemerintahan Belanda. Berangkat dari hal tersebut sehingga memicu golongan intelektual untuk membuat pers yang berpihak pada pergerakan nasional. Setelah itu banyak bermunculan koran-koran di Makassar.

Sinar Matahari dan Pemberita Makassar merupakan beberapa koran diantaranya yang terbit. Namun jauh sebelum itu, di Makassar telah terbit koran milik kolonial Belanda yang digunakan untuk kepentingan Belanda. Makassarsch Weekblad : Tahun 1 (1861)- Tahun 2 (1962) Macassar: Eenhout, 1861-1962. Mingguan teks dalam bahasa Belanda (Q: 512), dan Makassarsch Handels en Advertentieblad: Tahun 2 (1861)- Tahun 6 (1966). Macassar: Eenhout 1861-1966. Terbit dua kali seminggu. Teks dalam bahasa Belanda (Q: 286) (Farida, 2002).

Berdasarkan kutipan diatas, mengindikasikan bahwa surat kabar atau koran sudah dikenal masyarakat di Makassar sejak pertengahan abad ke-19, yaitu sekitar tahun 1861. Meskipun koran pada saat itu masih milik Belanda dan digunakan untuk kepentingan Belanda semata. Namun hal tersebut memiliki dampak positif bagi masyarakat di Makassar karena dapat mengetahui bentuk komunikasi baru (pers), serta mempelajari dan mengikuti mekanismenya. Dari beberapa surat kabar yang telah terbit di Makassar, surat kabar tersebut kurang mampu menyentuh pembaca secara luas. Hal ini terjadi karena masih minimnya penduduk di Makassar yang memiliki pendidikan, sehingga hanya beberapa orang saja yang dapat membaca dan mengartikan bahasa Belanda.

Kemudian kaum terdidik menerbitkan Koran berbahasa melayu, selanjutnya berbahasa Indonesia untuk kepentingan rakyat. Sehingga pada perkembangannya dapat menggunakan Koran sebagai alat perjuangan di Makassar.

Dalam kurun waktu tahun 1945-1953, terdapat 39 Koran yang terbit di Makassar. Namun dari semua Koran tersebut, hanya Pedoman Rakyat yang mampu bertahan. Selebihnya tidak mampu bertahan disebabkan oleh faktor finansial dan manajemen perusahaan yang tidak dapat mengikuti perkembangan. Barulah pada tahun 1981, di Makassar terbit Surat kabar harian, yaitu Surat Kabar Harian Fajar. Surat kabar ini dibawah naungan Jawa Pos. Surat kabar ini terbit pada tanggal 1 Oktober 1981. Baru setelah itu muncul beberapa Koran di Makassar, seperti Berita kota dan Ujung Pandang Ekspress.

Lambatnya perkembangan Surat kabar di Makassar, selain faktor internal seperti tidak mantapnya manajerial, minimnya daya operasional, juga dapat disebabkan oleh faktor eksternal seperti kurangnya kebijakan dari pemerintah yang mendukung ke arah kebebasan pers yang lebih baik lagi. Serta kurangnya antusias masyarakat untuk membaca menjadi faktor lain dalam lambatnya perkembangan Surat kabar di Makassar. Namun, beberapa tahun setelah itu, banyak Surat kabar baru terbit di Makassar, salah satunya adalah Koran Tribun Timur.

\section{Latar Belakang Lahirnya Koran Tribun Timur}

Hadirnya Koran Tribun Timur di Makassar bukan tanpa alasan. Lahirnya Koran Tribun Timur di latar belakangi oleh beberapa faktor. Faktor-faktor tersebut antara lain: 


\section{a. Populasi Penduduk di Makassar}

Dalam upaya untuk mendirikan sebuah Koran, populasi penduduk perlu diperhatikan sebagai faktor yang akan menunjang keberhasilan penerbitan Koran tersebut. Populasi penduduk di Makassar cukup besar, yaitu 1.179.023 jiwa (Kabupaten/Kota, 2004). Tingginya populasi penduduk dapat mengidikasikan bahwa kebutuhan akan informasi banyak karena manusia memiliki rasa ingin tahu yang tinggi. Baik seputar Kota Makassar maupun di luar Kota Makassar. Dengan kata lain, semakin tinggi populasi penduduk, maka mendirikan bisnis media cetak berupa informasi yaitu Koran, sangat menjanjikan di Makassar.

\section{b. Makassar sebagai Kota terbesar di Indonesia Timur}

Makassar merupakan Kota utama pintu gerbang Indonesia Timur. Sehingga tingkat ekonomi Kota Makassar cukup tinggi. Sebagai Kota terbesar di Indonesia Timur, perputaran uang di Makassar relatif lancar. Selain itu, pendapatan perkapita di Makassar tinggi sehingga memungkinkan untuk mendirikan perusahaan Koran di Makassar (Mappanganro, 2018).

\section{c. Kurangnya Koran Harian di Makassar}

Tingginya populasi penduduk di Makassar tidak sebanding dengan Koran yang ada di Makassar. Koran harian yang mengalami perkembangan di Kota Makassar pada tahun 2003 adalah Koran harian Fajar, Ujung Pandang Ekspress, dan Berita Kota. Namun Koran yang mendominasi dalam sirkulasi adalah Koran Fajar di bawah naungan Jawa Pos. Dari faktor inilah yang kemudian melahirkan sebuah keinginan untuk mendirikan Koran harian di Makassar.

\section{d. Permintaan Jusuf Kalla}

Melihat Koran kompas yang ada di Jakarta mengalami perkembangan yang pesat, sehingga Yusuf Kalla meminta Kompas untuk menerbitkan Koran daerah di Makassar. Akhirnya setelah melakukan survei di Makassar, KompasGramedia kemudian bekerja sama dengan Bosowa
Group untuk melahirkan Koran di Makassar (Mappanganro, 2018).

3. Lahirnya Koran Tribun Timur

Sejarah Koran Tribun Timur dimulai pada tahun 2003 dimana salah satu pengusaha daerah yang bernama M. Aksa Mahmud (pendiri PT. Bosowa) mempunyai keinginan untuk mendirikan perusahaan media cetak dalam bentuk Koran. Keinginan tersebut juga berdasarkan atas kondisi Koran di Kota Makassar yang terbilang sedikit. Sehingga menjadi peluang bisnis yang baik. Kesempatan ini pun tidak di sia-siakan oleh Aksa Mahmud.

Berdasarkan latar belakang kewartawanan dari Aksa Mahmud yang membuat dia menyadari bahwa arus informasi terhadap kejadian-kejadian di kota lambat sampai dan tersebar di Makassar. Karena pengiriman dan penerimaan Surat Kabar dari Jakarta ke Makassar berselang satu hari. SehinggaAksa Mahmud berkumpul dengan teman-teman lamanya untuk menerbitkan Surat Kabar di Makassar. Agar arus informasi tidak lambat sampai di Makassar.

Untuk itu, agar dapat berjalan dengan baik, Surat kabar tersebut bekerja sama dengan surat kabar di Jakarta. Upaya yang dilakukan oleh Aksa Mahmud menghubungi Surat Kabar yang ada di Jakarta yaitu Surat Kabar Harian Kompas. Karena Jusuf Kalla juga meminta Kompas untuk mendirikan Koran di Makassar. Setelah melakukan diskusi bersama antara M Aksa Mahmud (Bosowa Group) dan Yakub Oetama (Kompas Gramedia), akhirnya terjadi kesepakatan untuk bekerja sama (Ngantung, 2017).

Akhirnya terjadi kesepakatan diantara para pemimpin dari perusahaan yang bertemu. Nama perusahaan yang akan menaungi Koran yang akan terbit tersebut adalah PT. Bosowa Media Grafika. Meskipun Bosowa Group adalah kelompok usaha terkemuka yang berbasis di Makassar, namun dalam wilayah percetakan Kompas Gramedia lebih unggul. Dari hasil kesepakatan untuk 
wilayah teknis (Redaksi) diberikan wewenang kepada Kompas untuk mengaturnya. Sedangkan di wilayah perusahaan diberikan kepada Bosowa. Nama Koran Tribun Timur pun diambil dari kesepakatan bersama. Maksud dari penamaan tersebut yakni tribun (panggung) yang tinggi sehingga siapa saja bisa naik di panggung tersebut dan yang ada di tribun akan terlihat oleh semua orang. Dari makna tersebut memiliki harapan bahwa Koran yang akan terbit nantinya dapat dilihat oleh siapa saja secara luas. Sedangkan timur sendiri diambil berdasarkan letak wilayah Makassar, yakni di wilayah Timur. Jadi secara lengkap artinya yaitu Surat kabar yang terbit di wilayah Timur (Makassar) dan bisa di lihat oleh masyarakat luas tentang situasi teraktual dan bersifat Independen Marianto, 2018).

Pada tgl 9 Februari 2004 bertepatan dengan hari Pers Nasional, Koran Tribun Timur terbit untuk kali pertama. Namun karena PT. Bosowa Media Grafika belum memiliki percetakan, akhirnya bercetak di percetakan Sulawesi Jl. Elang (Sekarang Jl. Andi Mapanyukki). Sebagai salah satu Surat kabar yang Benefit, Koran Tribun Timur harus memiliki kantor sendiri. Akhirnya dipilihlah lokasi di Jl. Cendrawasih yang dulunya merupakan gedung Assembling Mobile Hole (showroom Mobil) dimana tempatnya luas sehingga sangat cocok untuk dijadikan Kantor Tribun Timur. Setelah direnovasi, akhirnya Koran Tribun Timur resmi berkantor di tempat tersebut. Peresmian Kantor tersebut dilakukan oleh M. Aksa Mahmud (Ngantung, 2017).

Dalam perusahaan media cetak khususnya koran, karyawan merupakan salah satu komponen yang sangat penting dalam mencapai kesuksesan. Perekrutan karyawan Tribun Timur dilakukan dengan metode yang hampir sama pada umumnya. Pada awalnya dilakukan pengumuman lowongan pekerjaan. Penyeleksian berkas, Interview, mengikuti tes psiko, dan tes tertulis. Pengumumannya akan dilakukan di Koran dan media online. Setelah dinyatakan lulus, karyawan tersebut akan di training terlebih dahulu.

Guna mencari informasi untuk di muat dalam Koran yang akan diterbitkan, wartawan dari sebuah Koran harus memiliki kemampuan dalam peliputan. Perekrutan wartawan dilakukan sebelum terbit untuk kali pertama. Calon wartawan yang direkrut adalah orang-orang muda yang baru lulus Perguruan Tinggi, karena dianggap masih segar dan bersemangat. Wartawan yang sudah bergelut di bidang Jurnalistik pun boleh mendaftar dengan catatan usianya masih muda.

Calon wartawan yang direkrut berasal dari berbagai disiplin ilmu dan sebagian besar belum memiliki kemampuan terkait jurnalistik. Sehingga mereka harus mengikuti pelatihan di gedung Mercedes (Gedung pertama Tribun Timur) Jl. Perintis Kemerdekaan dan yang memimpin pelatihan adalah orang Kompas yakni Valens Doi (almarhum). Pelatihan dimulai sejak September 2003. Selama enam bulan di latih sebelum penerbitan, akhirnya mereka siap untuk dikirim ke lapangan. Sebelum terbit, Tribun Timur sering melakukan simulasi guna melihat kesiapan untuk terbit dan sekaligus melihat kondisi di lapangan (Ngantung, 2017).

\section{Mekanisme Kerja Tribun Timur}

Agar terjadi pembagian job yang jelas dan terstruktur dengan baik, olehnya itu pemilik Koran Tribun Timur membagi dua manajemennya, yakni pemimpin umum dan pemimpin perusahaan. Secara garis besarnya kedua manajemen ini memang terpisah tetapi sudah menjadi satu kesatuan, dimana pemimpin umum memiliki tugas ganda, yaitu memperhatikan penebitan surat kabar juga mengatur manajemen perusahan penerbitan. Sedangkan pemimpin perusahaan bertugas untuk mengembangkan perusahaan yang mengatur persebaran surat kabar termasuk pemasukan iklan dan kerja sama dengan pihak lain.

\section{Bagian Perusahaan}




\section{a. Umum/administrasi dan Personalia}

Bertugas mengurus dokumentasi dan usaha-usaha lain yang berkenan dengan pekerjaan ke administrasian/tata usaha, juga menyangkut kesejahteraan, kebersihan, kendaraan dan perbekalan.

\section{b. Sirkulasi/pemasaran}

Bagian ini bertugas mendistribusikan surat kabar dari percetakan ke tangan pembaca akhir, utamanya dengan menggunakan pemasaran via agen, membentuk sistem dan standar pelayanan, menjawab ketersediaan surat kabar diseluruh wilayah Sulsel dan Sulbar.

\section{c. Keuangan}

Bagian ini mengurus masalah keuangan yang menunjang daur hidup proses produksi harian ini, termasuk penagihan pembayaran.

\section{d. Produksi}

Bagian ini menaungi urusan terbitnya hasil yang dikerjakan bagian redaksi. Sub bagian ini terkait dengan setting layout (tata letak), reproduksi dan percetakan.

\section{e. Iklan}

Bertugas mengkoordinasikan isi surat kabar yang berhubungan dengan periklanan, termasuk upaya-upaya pengembangan perolehan iklan sebagai salah satu sumber pendapatan perusahaan. Bagian ini menerima order iklan, melakukan pemasaran iklan. Bagian iklan Koran Tribun Timur dikenal dengan Account Executive yang bertugas mencari iklan sebagai pemasukan atau pendapatan perusahaan.

\section{f. Promosi}

Bertugas mengembangkan perusahaan dan menciptakan image untuk menjalin kerja sama dan memberikan pelayanan purna jual yang baik kepada pelanggan baik pemasang iklan maupun pelanggan Koran.

\section{Bagian Redaksional}

Dalam kegiatan operasional redaksi, masing-masing desk membawahi sejumlah reporter. Masing-masing desk memiliki halaman yang harus diisi setiap penerbitan dengan materi yang berkaitan dengan bidang desknya pula. Reporter bertanggung jawab kepada masing-masing redaktur dari desk yang mereka bidangi.Selain itu, reporter bertanggung jawab kepada masingmasing redaktur penanggung jawab rubrik tertentu. Sedangkan penanggung jawab rubrik itu sendiri bertanggung jawab langsung kepada redaktur di halaman mana rubrik tersebut ditempatkan.

Sebagaimana layaknya sebuah penerbitan pers, Koran Tribun Timur juga memiliki struktur keredaksian dengan komposisi sebagai berikut:

a. Pemimpin Redaksi

Pemimpin Redaksi dibantu oleh Wakil Pemimpin Redaksi dan Sekretaris Redaksi.

Pemimpin Redaksi bertanggung jawab langsung terhadap jalannya proses redaksional, antara lain:

1) Secara umum bertugas menyelenggarakan operasional redaksi dan berwenang mengatur serta melancarkan jalannya organisasi redaksi.

2) Memberikan penugasan kepada anggota redaksi dan para redaktur, reporter dan koresponden

3) Bertugas mengarahkan dan mengatur draf-draf yang menyangkut perwajahan

\section{b. Manajemen Produksi}

Manajemen produksi bertanggung jawab terhadap lancar tidaknya produksi koran, dengan kata lain seorang Manajer produksi bertanggung jawab terhadap penerbitan koran. Selain itu bertanggung jawab terhadap berita yang disajikan secara umum. Manajer produksi juga bertanggung jawab terhadap kesejahteraan para reporter dan para layouter sehingga ia dapat mengajukan saran-saran yang berhubungan dengan kesejahteraan para karyawan pada bagian produksi Koran ( Marianto, 2018).

5. Perkembangan Koran Tribun Timur Makassar (2004-2016)

a. Koran Tribun Timur pada Masa Uki M. Kurdi (2004-2008)

Koran Tribun Timur merupakan Perusahan Penerbitan di bawah naungan PT. Indo Persada Kompas. Koran harian ini hadir dengan warna baru, dengan 
dilengkapi dengan sajian Visual berupa Foto dan Grafis yang dominan. Selain itu harian ini tampil dengan tujuh kolom secara dinamik. Hadir dengan 24-32 halaman membuat Koran Tribun Timur meramaikan persaingan industri Surat kabar di Kota Makassar. Saat ini Koran Tribun Timur merupakan Koran ke dua belas di antara Koran daerah yang sudah berdiri dibawah naungan persda.

Pada awal terbit pada tahun 2004, hingga 2008 pemimpin redaksi pada Tribun Timur adalah Uki M Kurdi. Uki M Kurdi ditunjuk langsung oleh PT. Bosowa Media Grafika karena dalam hal keredaksian beliau bisa diandalkan. Selain itu, Uki M Kurdi juga ikut andil di dalam pelatihan bagi calon wartawan Koran Tribun Timur.

\section{1) Readership}

Hadirnya Koran Tribun Timur sangat dinanti-nanti oleh pembaca Koran. Mereka bertanya-tanya seperti apa model dari Koran Tribun Timur tersebut. Dari segi Readership atau jumlah pembaca, Koran Tribun Timur pada awalnya tidak memiliki begitu banyak pembaca. Karena sudah ada Koran yang lebih dulu terbit dan lebih terkenal di banding Koran Tribun Timur. Sejak masuk suvei Nielsen Media Research pada Juni 2004, jumlah pembaca Koran Tribun Timur adalah 12.000 readership (Timur, 2018). Namun pada tahun 2005 sampai tahun 2006, jumlah pembaca Koran Tribun Timur mengalami perkembangan yang signifikan hingga mencapai $180 \%$, atau 21.600 readership (Mappanganro, 2018)

\section{2) Rubrik}

Dari segi rubrik, Koran Tribun Timur mencoba untuk memenuhi kebutuhan akan informasi masyarakat dengan berbagai macam rubriknya. Mulai dari kehidupan sosial, politik, ekonomi, sampai olahraga. Pada tahun 2004, rubrik pada Koran Tribun Timur yaitu: Tribun Sul-Sel, Tribun Soccer Style, Tribun PSM Mania, Tribun Probis, Tribun Politik, Tribun Menuju Istana, Tribun Sport Hot News, Tribun Nasional/International, Tribun
Line, Tribun Makassar, Tribun Big Challenge, Tribun Super Ball, Tribun Soccer Hot News, Tribun Opini, Tribun Public Services, Tribun leisure, Tribun Seleb, Tribun Palopo, Tribun Bone, Tribun Maros-Gowa, dan Tribun ParePare (Timur, 2004).

Dari rubrik tersebut disesuaikan dengan kondisi di masyarakat. Tentunya berdasarkan dari hasil observasi yang dilakukan pihak tribun timur. Seperti rubrik Tribun Menuju Istana yang kondisinya pada saat itu menuju pemilihan Presiden Republik Indonesia periode 2004-2009. Begitu pula dengan rubrik olahraga yang memberitakan tentang olahraga baik di Indonesia maupun di Luar Indonesia. Namun terdapat khusus rubrik yang memberitakan tentang Club Sepak Bola, Kota Makassar itu sendiri, yaitu Rubrik PSM Mania. Dalam rubrik tersebut tribun timur memberitakan tentang hal-hal yang menarik dalam PSM dan juga Sporternya. Selain itu terdapat pula rubrik tentang perkembangan bisnis dan lowongan pekerjaan.

Setelah beberapa tahun berkembang, Koran Tribun Timur melakukan perubahan. Pada rubrik terjadi penambahan yang awalnya 21 menjadi 23. Rubrik tersebut sebagai berikut: Tribun Nasional, Tribun Internasional, Tribun Celluler Style, Tribun Politik, Tribun Line, Tribun Public services, Tribun Big Challenge, Tribun Bisnis, Tribun Makassar, Tribun Metro dan Hukum, Tribun Edu, Tribun Komunitas, Tribun Gowa-Maros-Bulukumba, Tribun Ajatappareng, Tribun Bone, Tribun Luwu Raya, Tribun PSM, Tribun Super Ball, Tribun Soccer Hot News, Tribun Seleb Life Style, Tribun Sport Hot News, Tribun Pemilu, dan Tribun Opini (Timur, 2008).

Dari rubrik tersebut terjadi penambahan rubrik (Celluler Style dan Komunitas) dan pergantian nama rubrik (Bisnis, Luwu Raya, Edu, dan Pemilu), serta pemecahan rubrik (Nasional dan Internasional). Sedangkan rubrik Ajatappareng sendiri adalah perubahan 
dari rubrik pare-pare sekaligus penambahan wilayah disekitarnya, seperti Pinrang, Barru, dan Pangkep. Selain rubrik, dari segi halaman juga terjadi perubahan, yang awalnya 28 halaman pada tahun 2008 menjadi 32 halaman. Perubahan tersebut berdasarkan kesepakatan bersama dari Grub of Regional Newspaper.

3) Karyawan

Dalam suatu perusahaan, karyawan merupakan hal yang sangat penting untuk perkembangannya. Karyawan harus memiliki kreativitas, semangat dan konsisten dalam bekerja. Untuk perkembangan karyawan sendiri, tribun timur memiliki cara tersendiri. Cara tersebut yaitu melakukan pelatihan berdasarkan kebutuhan. Perlu diperhatikan posisinya apa, latar belakangnya apa dan dinilai kekurangannya dimana untuk diberikan pelatihan yang sesuai.

Pada tahun 2008, Tribun Timur juga menerapkan Badan Portal. Dengan badan portal tersebut, maka setiap karyawan memiliki Buku Indikator Penilaian atau sejenis buku laporan. Dalam buku tersebut apa yang mau dinilai dan berapa targetnya kemudian di evaluasi berapa total nikainya. Ini merupakan model pembelajaran langsung atau pelatihan langsung, karena mereka dituntut untuk bekerja mencapai target.

Karyawan yang memiliki kemampuan dan kreatifitas yang tinggi memang sangat diperlukan dalam suatu perusahaan agar dapat berkembang dengan pesat. Kurangnya sumber daya manusia yang sesuai dengan kualifikasi menjadi kendala yang dialami oleh Tribun Timur. Hal ini disebabkan bahwa perusahaan media berbeda dengan perusahaan lainnya karena perusahaan media adalah produk sehari, apa yang di kerjakan hari ini akan di dapat hasilnya besok. Jadi ketika merekrut karyawan dengan kualifikasi yang tidak sesuai, maka dibutuhkan waktu yang lama lagi dan itu dapat menghambat proses kerja Total karyawan pada saat terbit sekitar 80 Orang (Mappanganro, 2018).
Namun tingginya curah kerja dalam perusahaan ini merupakan faktor yang mempengaruhi karyawan. Adaptasi dengan kondisi tersebut sangat dibutuhkan agar karyawan dapat bertahan dengan waktu kerja tersebut. Seperti yang terjadi pada Muhary Wahyu Nurba, seorang yang kerja pada bagian lay out namun keluar pada tahun 2005 karena tidak bisa beradaptasi dengan jam kerja perusahaan.

\section{4) Posisi Koran Tribun Timur}

Dalam gaya bahasanya, Koran Tribun Timur menggunakan gaya bahasa yang mudah dimengerti oleh pembacanya. Selain itu, Koran Tribun Timur juga menggunakan kalimat yang pendek namun jelas. Dalam penataan halamannya, tribun timur banyak menampilkan gambargambar karena daya tarik mata pembaca terutama pada gambar. Gambar yang dimuat mewakili dari isi berita yang disajikan, sehingga dengan melihat gambar tersebut, maka pembaca dapat mengetahui isi dari berita tersebut.

Kelebihan Koran Tribun Timur dibandingkan dengan Koran yang lain yaitu Koran Tribun Timur berada dalam naungan perusahaan yang terkemuka di Indonesia yaitu Bosowa dan Kompas. Sehingga memiliki modal yang cukup. Selain itu salah satu perusahaan (Kompas) sudah berpengalaman di bidang industri media cetak sehingga sudah ada pengalaman tentang membangun Koran. Kelebihan yang lain yaitu Sumber Daya Manusia dari Koran Tribun Timur yang mayoritas adalah Sarjana. Sehingga kemampuannya tinggal di kembangkan. Selain itu, pada awal terbit, Koran Tribun Timur merupakan Koran termurah di Makassar dengan jumlah halaman hamper sama dengan Koran lainnya, yaitu 24 halaman (Mappanganro, 2018).

Koran Tribun Timur mendapat sambutan yang luar biasa dari pasar sejak awal penerbitannya. Koran Tribun Timur sekarang menjadi salah satu Koran utama dan terkemuka di Makassar. Iklan Koran Tribun Timur Tahun 2008, menurut Nielsen yang menyebutkan bahwa hampir 
50 persen dari pangsa pasar iklan Surat kabar di Makassar, dimiliki oleh Koran Tribun Timur. Sedangkan sisa dari pangsa pasar tersebut diperebutkan oleh empat Koran lain yang terbit di wilayah Makassar (Ramadhan, 2012).

Dalam kisaran 3-4 tahun setelah terbit, perkembangankoran tribun timur mengalami peningkatan. Menurut pengamatan dari Nielsen bahwakoran tribun timur sudah bisa mencapai Brige Event Point artinya Koran tribun timur sudah bisa menutupi biaya-biaya pengeluaran dengan penghasilan dari hasil penjualan dan iklan. Beberapa pengamat pers di Makassar mengatakan bahwa Koran Tribun Timur menjadi Koran yang fenomenal karena pencapaian tersebut dalam waktu yang singkat. Koran lain biasanya berumur sepuluh tahun baru bisa mencapai targetan tersebut. Jika diibaratkan bahwa Koran Tribun Timur ibarat bayi yang sudah bisa berjalan dan berlari (Ngantung, 2017).

\section{b. Koran Tribun Timur pada Masa Dahlan Dahi (2008-2016) \\ Menjelang akhir Tahun 2008} pemimpin redaksi Koran Tribun Timur mengalami pergantian. Uki M. Kurdi digantikan oleh Dahlan Dahi. Faktor yang menjadi penyebab terjadinya pergantian tersebut adalah karena kompasdi Jakarta mengalami perkembangan yang pesat, sehingga Uki M. kurdi dipanggil kembali untuk ke Jakarta. Sedangkan yang di Tribun Timur digantikan oleh Dahlan Dahi yang sebelumnya sebagai Redaktur Pelaksana.

Pada masa Dahlan Dahi, dari segi perubahan yang terjadi tidak begitu jauh berbeda dengan masa Uki M Kurdi. Namun ada beberapa perubahan yang terjadi, meskipun perubahan tersebut terjadi atas kesepakatan bersama di group bukan dari kemauan Dahlan Dahi seorang. Perubahan tersebut terbagi menjadi beberapa aspek.

\section{1) Readership}

Pada tahun 2014 tiap bulannya mengalami peningkatan dari readership.
Dan mengalami

puncaknya pada bulan Oktober, yaitu 255.000 per hari. Sedangkan untuk bulan selanjutnya mengalami penurunan sampai awal tahun 2015. Pada akhir 2015 baru mengalami peningkatan secara terus menerus sampai puncaknya pada Juni 2016, yaitu 287.000 per hari. Setelah itu pun readership dari Koran Tribun Timur terus mengalami penurunan. Hingga Desember 2016, readership Koran Tribun Timur hanya 170.000 per hari. Sampai saat ini sejak munculnya koran tribun timur dalam bentuk Online, pada Juni 2016 tersebut yang paling tinggi readershipnya (Research, 2017).

\section{2) Rubrik}

Rubrik pada masa ini pengalami penambahan menjadi 27. Rubrik tersebut ada pula yang mengalami perubahan nama dari sebelumnya. Adapun rubrik tersebut yaitu: Tribun Nasional, Tribun Bisnis, Tribun Finance, Tribun Probis,tribun VIP, Tribun Line, Tribun Buffer, Tribun Makassar, Tribun Makassar Life, Tribun Komunitas, Tribun Skul, Tribun PT Ideal, Tribun SulSel, Tribun Politik, Tribun Opini, Tribun Property, Tribun Automoto, Tribun Travel Culinary, Tribun Citizen, Tribun Public Services, Tribun Seleb, Tribun Super Ball, Tribun Hit News, Tribun Jual Beli, Tribun Super Sport, Tribun Sport Hot News, dan Tribun PSM (Timur, 2018). Rubrik pada Koran Tribun Timur menyesuaikan pada kebutuhan dan zaman. Ada rubrik yang permanen dan ada rubrik yang berubah-ubah berdasarkan kondisi atau momen. Beberapa Rubrik yang tetap bertahan, antara lain rubrik Politik, Pemilu, Opini, Sport, PSM, Seleb, Nasional, Tribun Makassar, Tribun Kampus, Tribun Daerah, Tribun Sul-Sel, dan Tribun Citizen (Mappanganro, 2018).

\section{3) Karyawan}

Karyawan Koran Tribun Timur mengalami penambahan berdasarkan kebutuhan dan kondisi yang terjadi di Perusahaan. Jumlah karyawan Tribun Timur saat ini adalah 130 dengan jumlah 
wartawan 32 orang. Sedangkan untuk pengembangan karyawan tetap dilakukan pada masa Dahlan Dahi. Selain itu juga, pada masa ini dalam pengembangan karyawan juga melakukan penugasan ke unit lain untuk membantu. Selain membantu mereka juga bisa belajar dalam hal Menejerialnya bukan teknisnya. Waktu yang diberikan bervariasi. Ada yang satu bulan, dua bulan, tiga bulan, bahkan bertahun- tahun. Namun ketika sudah bertahun- tahun karyawan tersebut dipindahkan ke unit lain, biasanya karyawan tersebut di mutasikan atau dipindahkan ke unit tersebut. Karena dianggap lebih berkompeten di unit tersebut. Atau disebut juga dengan promosi untuk kenaikan jabatan ( Marianto, 2018).

Pada masa Uki M Kurdi penambahan karyawan juga dilakukan berdasarkan kebutuhan. Terdapat pula karyawan yang keluar karena keinginannya sendiri. Salah satunya adalah Hairul Fadli yang keluar pada tahun 2015. Alasannya keluar adalah karena jam kerja yang padat dan karena sedang melanjutkan study di pasca sarjana.

\section{4) Posisi Koran Tribun Timur}

Dalam perkembangannya, Koran Tribun Timur terus mengalami kemajuan. Dalam Readership, Koran Tribun Timur menjadi Koran dengan jumlah readership terbanyak di Makassar (Research, 2017). Selain itu, dalam media online, Tribun Timur yang tergabung dengan Tribun lainnya dalam Tribun News.com menjadi Koran terbanyak pengunjungnya di antara Koran lainnya. Dalam posisi dengan Tribun lainnya, portal Tribun Timur menjadi pensuplai berita terbanyak diantara Tribun lainnya (Mappanganro, 2018).

\section{E. Kesimpulan}

Latar belakang lahirnya Koran Tribun Timur diawali karena adanya faktor yang menyebabkannya. Faktor-faktor tersebut yaitu: Populasi penduduk Makassar yang tinggi, Makassar sebagai Kota terbesar di Indonesia Timur, Kurangnya Koran Harian di Makassar, serta adanya permintaan dari Jusuf Kalla kepada
Kompas untuk menerbitkan Koran di Makassar. Dari faktor tersebut M. Aksa Mahmud bekerja sama dengan Yakub Oetama untuk mendirikan Koran yang bernama KoranTribun Timur, terbit pada tanggal 9 Februari 2004 untuk kali pertama. Perkembangan Koran Tribun Timur pada masa Uki M Kurdi dan Dahlan Dahi sebagai Pemimpin Redaksi, dari segi rubrik terjadi perkembangan dengan penambahan rubrik. Karyawan juga dikembangkan kemampuannya dengan pelatihan, penugasan ke unit lain, dan menerapkan badan portal. Selain itu, pada tahun 2016, Koran tribun timur mencapai angka terbesar dalam hal readership yaitu 287.000 per hari.

\section{DAFTAR PUSTAKA}

Anon., 2004. profil kabupaten/kota Makassar Sulawesi selatan. [Online] Available at: www.makassar.com [Accessed 7 November 2017].

Effendi, O. U., 1997. Ilmu, Teori, dan Filsafat Komunikasi. Bandung: PT. Citra Aditya Bakti.

Farida, 2002. Perkembangan Harian Pedoman Rakyat di Makassar. Makassar, FIS UNM.

Kabupaten/Kota, P., 2004. Kota Makassar Sulawesi Selatan. [Online]

Available at: www.makassar.com [Accessed 7 November 2017].

Kominfo, 2017. Saatnya Kita Melek Media - Pengetahuan Dan Rujukan Bagi Khalayak Media. Jakarta: Kominfo.

Madjid, M. S., 2012. Pengantar IImu Sejarah. Makassar: FEIS UNM.

Mappanganro, J., 2018. wawancara [Interview] (15 Mei 2018).

Marianto, S. 2018. wawancara [Interview] (15 Februari 2018).

Michael, B. d., 2004. Hubungan Media Yang Efektif. Jakarta: Erlangga.

Ngantung, R., 2017. wawancara [Interview] (1 November 2017).

Ramadhan, S., 2012. Analisis Penerapan Konsep Penyeimbang Lini (Line 
Balancing) Pada Sistem Produksi

Percetakan Harian Tribun Timur.

Makassar, UNHAS.

Research, N. M., 2017. Readers Report in

Makassar Q3 2017, Jakarta: The

Nielsen Company.

Teguh, T., 2016. Jurnalistik Komperhensif.

Yogyakarta: Penerbit Ombak.

Timur, K. T., 2004. Edisi 9 Februari,

Makassar: Tribun Timur.

Timur, T., 2008. Edisi 4 Agustus,

Makassar: Koran Tribun Timur.

Timur, K. T., 2018. Edisi 3 April 2016,

Makassar: Tribun Timur.

Timur, T., 2009. ProfilTribunTimur.com.

[Online]

Available at:

http://blogtribuntimur.blogspot.co.id/

2009/11/profil-tribun-timur.html

[Accessed 19 April 2017].

Timur, T., 2018. Nielsen Media Research :

Tribun Timur Tumbuh 20 Kali

Lipat. [Online]

Available at:

http://makassar.tribunnews.com/2015

/02/26/nielsen-tribun-timur-tumbuh-

20-kali-lipat-sejak-2004

[Accessed 17 Mei 2018]. 